\title{
Moving Beyond the Stigma: Systematic Review of Video Games and Their Potential to Combat Obesity
}

\author{
Stacey Guy, Alexandria Ratzki-Leewing, and Femida Gwadry-Sridhar \\ I-THINK Research, Lawson Health Research Institute, Parkwood Hospital, 801 Commissioners Road East, Suite B3041, \\ London, ON, Canada N6C 5J1
}

Correspondence should be addressed to Femida Gwadry-Sridhar, femida.gwadry-sridhar@lhsc.on.ca

Received 16 January 2011; Accepted 1 February 2011

Academic Editor: Kazuko Masuo

Copyright (C) 2011 Stacey Guy et al. This is an open access article distributed under the Creative Commons Attribution License, which permits unrestricted use, distribution, and reproduction in any medium, provided the original work is properly cited.

Increasing epidemic proportions of overweight children in the United States presents formidable challenges for education and healthcare. Given the popularity and pervasiveness of video gaming culture in North American children, the perfect opportunity arises to investigate the potential of video games to promote healthful behaviour. Our objective was to systematically review the literature for possible benefits of active and educational video games targeting diet and physical activity in children. A review of English-language journal articles from 1998 to 2011 using EMBASE and PubMed was conducted. Thirty-four studies concerned with children, video games, physical, and/or nutritional outcomes were included. Results of these studies that showed some benefit (increased physical activity and nutritional knowledge as a result of gaming) demonstrate the possibility of video games to combat childhood obesity-looking beyond the stigma attached to gaming.

\section{Introduction}

Overweight or obesity among American children has reached epidemic proportions [1]. Over the past 25 years, childhood overweight or obesity has nearly quadrupled in the United States, affecting almost $17 \%$ of children and adolescents aged 2-19 in 2007-2008 [2, 3]. Childhood overweight or obesity is defined as having a body mass index (BMI) greater or equal to the age- and sex-specific 95th percentile of the 2000 Centre for Disease Control growth charts [3]. Overweightobese youth are increasingly suffering from comorbid conditions once considered limited to adults [4]. Despite considerable efforts to halt or reverse the growing rates of childhood overweight or obesity, the incidence continues to escalate.

Paediatric overweight or obesity has been implicated in a myriad of serious health concerns. Short-term consequences of overweight-obese status include chronic orthopedic and psychological disorders, nonalcoholic fatty liver diseases, metabolic syndrome, as well as a host of cardiovascular diseases such as hypertension and Type II diabetes mellitus $[5,6]$. Long-term consequences have proven the persistence of childhood obesity into adulthood, with an estimated $50 \%$ of obese adolescents becoming obese adults [6]. This persistence into adulthood incites a cascade of cardiovascular risk factors and other chronic morbidities, dramatically increasing the risk for premature mortality [5]. The economic burden of overweight and obesity on the American healthcare system is expected to intensify with persevering rates of childhood overweight and obesity [7].

Physical activity and diet are important in the management of obesity. Increased rates of overweight and obesity among children have been attributed to an increase in sedentary pursuits and a decrease in physical activity [8]. Furthermore, children who participate in higher levels of physical activity are less likely to display risk factors for cardiovascular disease and more likely to have positive outcomes in weight regulation [9-13]. Motivating children to participate in physical activity may also preclude the persistence of childhood obesity into adulthood [14, 15]. Promoting optimal physical activity levels among children can reduce the overall incidence and prevalence of overweight and obesity $[16,17]$. Further research is required to better explore and understand the relationship between physical activity and obesity prevention [18]. 
With growing rates of childhood overweight and obesity, it becomes increasingly more important to promote healthy eating as poor dietary behaviors are a known risk factor for the development of obesity $[19,20]$. In addition, nutritional deficits and poor eating habits that develop in youth have been implicated with long-term health, growth, and developmental issues [21]. Obesity often results from an energy imbalance, with a greater energy intake to expenditure, with overweight or obese youth less likely to compensate for excess energy intake throughout the day than normalweight children [22]. Research has identified physical activity and diet as factors implicated in childhood overweight. Exploring strategies that reduce overweight and obesity by targeting physical activity and healthy eating is a necessary endeavour.

The United States Department of Agriculture's dietary guidelines for Americans from the age of 2 years old focuses on balancing caloric intake with physical activity [23]. The message purported is to decrease the amount of calories consumed and increase calories expended through physical activity. To achieve this, the Surgeon General suggests the following for a healthy lifestyle: an increase in consumption of fruits, vegetables, whole grains, and lean proteins; reduction of sodas and juices with added sugars; increase amounts of water consumed; limit dairy products to low fat or nonfat; be more physically active, including limiting screen time to a maximum of 2 hours per day [24].

In addition, the Centers for Disease Control and Prevention recommends that children and adolescents partake in 60 minutes of physical activity a day. This should consist of aerobic activity (making up the bulk of the 60 minutes), muscle strengthening activities (a minimum of 3 days a week), and bone strengthening activities (a minimum of 3 days a week) [25].

Efforts to mitigate the formidable effects and prevalence of childhood overweight or obesity have been aimed at reducing sedentary behavior and poor nutrition [26]; indeed, compared to the rest of the world, early adolescents in the United States exhibit the worst rates of physical activity and the least healthy diets [27]. While several factors have been blamed for this disparity in healthy behavior, including preference for indoor pastimes, low energy levels, time constraints, unsafe neighborhoods, a lack of motivation, insufficient resources and poor social support [28], it is screen-based activities that seem to garner the most public criticism. While both watching television and playing video games have been accused of increased sedentariness among youth and growing rates of childhood overweight or obesity, video game playing has shown the strongest positive correlation, with the duration of screen time forecasting weight status [29, 30].

The United States houses the highest percentage of youth under 18 years of age using the internet, with approximately 93\% of teens (aged 12-17 years old) going online [31]. While only $15 \%$ of households do not have a home computer [32] $-83 \%$ of American youth have access to at least 1 video game console in their bedroom [28]. Thus, as a possible forward-thinking strategy, researchers can look at video gaming as a means of promoting physical activity and healthy nutrition among at-risk children, replacing passive screen time with active screen time [28]. Exergaming (video games that are a form of exercise) can be used to motivate direct physical activity in combating overweight and obesity among children. Similarly, interactive educational video gaming can aid in developing self-care abilities and healthy behavioral skill building.

The goal of this paper is to enlighten researchers to the possible benefits of active and educational video games targeting diet and physical activity in children. Our objective is to review the current literature on the role of video games (development and use) in the prevention of childhood overweight and obesity and provide a summary of findings that can be used to spur future research.

\section{Methods}

2.1. Data Sources. We conducted a systematic review of the literature utilizing the bibliographic databases EMBASE and PubMed in December 2010. The following search terms (MeSH headings for PubMed and keywords for EMBASE) were used: obesity, overweight, physical activity, fitness, exercise, energy expenditure, heart rate, energy metabolism, nutrition, BMI, diet, video gam*, exergam*, active video gam* $^{*}$, active computer gam*, new generation computer gam*, exertainment, active gam*, and computer gam*. Search terms were determined by examining the previous literature in the area.

The search was limited to articles written in the English-language and published between 1998 and 2011. Articles focusing on a 0 - to 18 -year-old population were included (Preschool child, School child, and Adolescent in EMBASE). All study design methodologies were considered. Two reviewers (S. Guy and A. R.-Leewing) hand searched references present in the included articles with a specific focus on journal articles discussing the use of video games to combat obesity.

2.2. Data Extraction and Synthesis. We retrieved 181 studies in total, 87 from EMBASE and 94 from PubMed. We ran a duplicate search which reduced the total to 128 articles. Further examination eliminated 4 references not classified as journal articles ( 2 were conference abstracts, 1 comment, and 1 forum document). Each article was reviewed by 2 reviewers (S. Guy and A. R.-Leewing). Articles were excluded if they only described the negative effects of screen time (watching television, playing video games, surfing the internet) on physical activity levels. Articles that only described obesity interventions in general without specific reference to video game interventions were also excluded. Of the 124 articles, 18 pertained to interventions utilizing video games and/or computer games. Upon hand searching references within retrieved articles, 18 journal articles were included (Figure 1). A previous literature review [33] was eliminated; however, it was examined for potentially useful references. Systematic reviews [26, 33-35] discovered during hand searching were used to inform study choice and discussion material. 
EMBASE $\quad$ PubMed

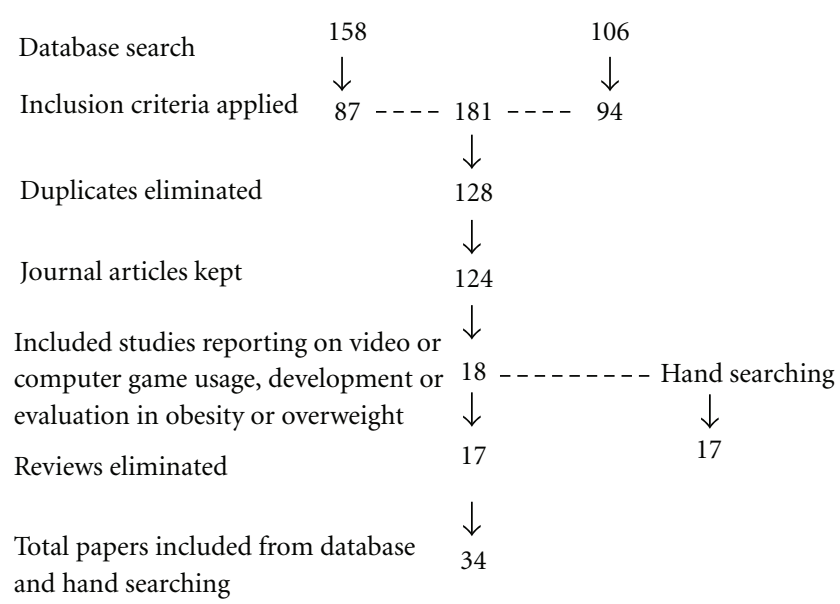

Figure 1: Identification of studies.

\section{Results}

The results are organized into sections based on the type of game (Table 1).

3.1. Exergaming. All studies in this section focused on exploring physical activity and on determining the amount of physical activity expended during active video game play. Physical inactivity is a contributing factor in the prevention of overweight and obesity.

Chin A Paw et al. (2008) [36] conducted a randomized controlled trial with a 12-week home-based Dance Dance Revolution (DDR) (Konami Digital Entertainment, Redwood City, CA) intervention. The comparison group received DDR to use as often as they desired, while the multiplayer group played DDR with other children once a week in a 60-minute class at a sports center. A total of 29 children with a low fitness level aged 9-12 years from 4 primary schools were recruited. Of the 27 randomly assigned, 11 children dropped out of the study. Chin A Paw et al. (2008) measured aerobic fitness, physical and sedentary activity through self-report, anthropometry, body composition, playing time through self-report, and perceived competence in sport. Results showed that the multiplayer group played the game more $(901 \mathrm{~min})$ than the comparison group (376 min); however, this was nonsignificant. Children reported finding the game boring after a while.

Epstein et al. (2007) [37] examined the reinforcing value and activity levels of active dance and bicycle games in 18 overweight and 17 nonoverweight children aged 8-12 years. Children engaged in a behavioral choice task for dancing or bicycling. There were 3 conditions for the dance game (dancing with music, dancing with a video, and DDR) and 3 conditions for the bicycle game (bicycle alone, bicycle with video, and Freekstyle) (Electronic Arts, Redwood City, CA). Findings show DDR to be more reinforcing than dancing alone or dancing while watching the video; however, no difference was found across the 3 bicycle conditions.
Nonoverweight children were more active playing the active dance game than overweight children.

Graf et al. (2009) [38] compared energy expenditure rates in children playing active video games in relation to treadmill walking. The sample comprised of 23 healthy children ranging in age from 10 to 13 years old. Participants were measured for energy expenditure, heart rate, step rate and perceived exertion watching television, playing DDR at 2 skill levels, playing Wii bowling and boxing (Nintendo, Redmond, WA), and walking at $2.6,4.2$, and $5.7 \mathrm{~km} / \mathrm{h}$. Energy expenditure while playing the active video games or walking increased 2- to 3-fold in comparison with watching television. Wii bowling and beginner level DDR elicited a 2fold increase in energy expenditure compared to watching television.

A study conducted in the United Kingdom compared energy expenditure during sedentary and active gaming [39]. Eleven participants aged 13-15 years played 4 computer games for 15 minutes each: sedentary XBOX 360 (Microsoft, Redmond, WA), Wii Sports bowling, tennis, and boxing. Graves et al. (2007) found that energy expenditure was 51\% greater during active gaming and highest during Wii Tennis. Male participants expended more energy during gaming than females. Graves et al. [40] further expanded on the energy expenditure in upper limb movement in comparison to total-body movement while engaged in sedentary and active video gaming. Youths between 11-17 years old played 3 active Wii games and one sedentary video game (XBOX 360). Energy expenditure, heart rate, and nondominant upper limb activity were significantly greater during boxing in comparison to tennis or bowling. Findings showed that hip activity best predicted energy expenditure.

Haddock et al. (2009) [41] measured oxygen consumption, energy expenditure, and perceived exertion during a comparison of stationary cycling with and without a video game. Children participating in this study $(N=20)$ were at risk for overweight and between the ages of 7-14 years old. Participants rode a stationary bicycle (CatEye Gamebike, USA) for 20 minutes. Testing session 1 consisted of riding the bicycle, while in session 2 the bicycle controlled the speed in the game Cars (Pixar Entertainment Inc.). Energy expenditure was significantly higher $\left(4.4 \pm 1.2 \mathrm{~K} \mathrm{cal} \mathrm{min}^{-1}\right)$ when cycling in conjunction with the video game than riding the bicycle on its own. There was no significant difference in perceived exertion between the 2 sessions.

A comparison of energy expenditure during sedentary video gaming and television viewing, active video game play, and treadmill walking was undertaken by LanninghamFoster et al. (2006) [42]. Energy expenditure was calculated while participants watched television seated, played a traditional video game seated (Disney's Extreme Skate Adventure Activision, Los Angeles, CA), watched television while walking on a treadmill at 1.5 mile per hour, and played active video games (Nicktoons Movin', THQ, Calabasas Hills, CA; DDR Ultramix 2). Twenty-five children aged 812 participated. Active video games resulted in a larger increase in energy expenditure than playing the traditional video game seated. Energy expenditure increased by $382 \pm$ $181 \mathrm{~kJ} /$ hour above levels of energy expended during rest. 
TABLE 1: Summary of studies included in the systematic review.

\begin{tabular}{|c|c|c|c|}
\hline Authors & Study description & Sample & Key findings \\
\hline \multicolumn{4}{|l|}{ Exergames } \\
\hline Chin A Paw et al., 2008 [36] & $\begin{array}{l}\text { Comparison of home-based } \\
\text { DDR and multiplayer DDR } \\
\text { sessions with a 12-week RCT. }\end{array}$ & $\begin{array}{l}16 \text { children with low fitness } \\
\text { between } 9 \text { and } 12 \text { years old } \\
\text { (mean } 10.6[0.8] \text { ) from } 4 \\
\text { primary schools. } 29 \text { recruited, } 27 \\
\text { randomly assigned, } 11 \text { dropped } \\
\text { out. }\end{array}$ & $\begin{array}{l}\text { Multiplayer group played more } \\
\text { ( } 901 \mathrm{~min}) \text { than home-based } \\
(376 \mathrm{~min}) \text {. Children reported } \\
\text { finding game boring after a while. }\end{array}$ \\
\hline Epstein et al., 2007 [37] & $\begin{array}{l}\text { Comparison study of activity } \\
\text { levels and reinforcement value in } \\
\text { active dance and bicycle games. }\end{array}$ & $\begin{array}{l}35(18 \mathrm{M}, 17 \mathrm{~F}) \text { overweight }(18) \\
\text { and nonoverweight }(17) \text { children } \\
\text { aged } 8 \text { to } 12(10.8[1.4]) .\end{array}$ & $\begin{array}{l}\text { Active dance game is more } \\
\text { reinforcing than dancing alone or } \\
\text { while watching video. No difference } \\
\text { found across } 3 \text { bicycle conditions. }\end{array}$ \\
\hline Graf et al., 2009 [38] & $\begin{array}{l}\text { Comparison EE rates playing } \\
\text { AVG (DDR, Wii) in relation to } \\
\text { treadmill walking }(2.62,4.2 \text {, and } \\
5.7 \mathrm{~km} / \mathrm{h}) \text {. }\end{array}$ & $\begin{array}{l}23(14 \mathrm{M}, 9 \mathrm{~F}) \text { healthy children } \\
\text { aged } 10 \text { to } 13(11.9[1.2]) \text { with a } \\
\text { mean BMI of } 19.1[3.1] \text {. }\end{array}$ & $\begin{array}{l}\text { EE increased 2- to 3-fold with AVG } \\
\text { play and walking compared to } \\
\text { watching TV. } 2 \text {-fold increase in EE } \\
\text { with bowing and DDR. }\end{array}$ \\
\hline Graves et al., 2007 [39] & $\begin{array}{l}\text { Determine EE with a cross } \\
\text { section of } 4 \text { games. }\end{array}$ & $\begin{array}{l}11(6 \mathrm{M}, 5 \mathrm{~F}) \text { children between } \\
13 \text { and } 15 \text { years }(14.6[0.5], \mathrm{BMI} \\
21.2[2.5])\end{array}$ & $\begin{array}{l}\text { EE was } 51 \% \text { greater during VG play. } \\
\text { Highest } \mathrm{EE} \text { with Wii Tennis. EE } \\
\text { greater for M versus } \mathrm{F} \text {. }\end{array}$ \\
\hline Graves et al., 2008 [40] & $\begin{array}{l}\text { Comparison of EE in upper } \\
\text { limbs versus total body } \\
\text { movement with sedentary and } \\
\text { active gaming. }\end{array}$ & $\begin{array}{l}13 \text { youths }(6 \mathrm{~F}, 7 \mathrm{M}) \text { between } 11 \\
\text { and } 17 \text { years }(15.1[1.4]) \text { with a } \\
\text { mean BMI of } 22.0[2.6]\end{array}$ & $\begin{array}{l}\text { Wii Boxing resulted in highest } \mathrm{HR} \text {, } \\
\text { EE, and nondominant upper limb } \\
\text { activity. }\end{array}$ \\
\hline Haddock et al., 2009 [41] & $\begin{array}{l}\text { Determine EE when riding } \\
\text { stationary bike with and without } \\
\text { a video game. }\end{array}$ & $\begin{array}{l}20 \text { children }(13 \mathrm{M}, 7 \mathrm{~F}) \text { at risk for } \\
\text { or overweight between } 7 \text { and } 14 \\
\text { years old. }\end{array}$ & $\begin{array}{l}\text { EE higher cycling with video game } \\
\text { than without. No sig. difference in } \\
\text { average perceived exertion. }\end{array}$ \\
\hline $\begin{array}{l}\text { Lanningham-Foster et al., } \\
2006 \text { [42] }\end{array}$ & $\begin{array}{l}\text { Comparison of EE during } \\
\text { sedentary gaming, watching TV, } \\
\text { AVG play, and treadmill walking. }\end{array}$ & $\begin{array}{l}25 \text { children }(12 \mathrm{M}, 13 \mathrm{~F}) \text { aged } 8 \\
\text { to } 12 \text { years }(9.7[1.6]) .15 \text { lean } \\
\text { and } 10(5 \mathrm{M}, 5 \mathrm{~F}) \text { with mild } \\
\text { obesity }\end{array}$ & $\begin{array}{l}\text { EE increased by } 108 \pm 40 \% \text { with } \\
\text { EyeToy and by } 172 \pm 68 \% \text { with } \\
\text { DDR. }\end{array}$ \\
\hline Maddison et al., 2007 [43] & $\begin{array}{l}\text { Comparison of EE and physical } \\
\text { activity during sedentary gaming } \\
\text { and AVG play. }\end{array}$ & $\begin{array}{l}21 \text { children }(11 \mathrm{M}, 10 \mathrm{~F}) \text { between } \\
10 \text { and } 14 \text { years old }(12.4[1.1]) \\
\text { with a mean BMI of } 20.3[4.0]\end{array}$ & $\begin{array}{l}\text { Step counts increased } 122 \text { to } 1288 \\
\text { during AVG play from sedentary } \\
\text { play. }\end{array}$ \\
\hline Maddison et al., 2009 [30] & $\begin{array}{l}\text { Overview of the eGAME study. } \\
\text { 2-arm parallel RCT to be carried. } \\
\text { Determine effects of AVG on } \\
\text { BMI, physical activity, } \\
\text { cardiorespiratory fitness, waist } \\
\text { circumference, and body } \\
\text { composition. }\end{array}$ & $\begin{array}{l}330 \text { overweight children between } \\
\text { the ages of } 10 \text { and } 14 \text { years. }\end{array}$ & $\begin{array}{l}\text { Phase 1: All children enjoyed AVGs. } \\
\text { Phase 2: EE sig. greater in AVGs } \\
\text { compared to rest and sedentary } \\
\text { gaming conditions. }\end{array}$ \\
\hline Madsen et al., 2007 [44] & $\begin{array}{l}\text { Pre-/post-6-mth } \\
\text { noncomparative trial. Determine } \\
\text { if overweight would use DDR for } \\
\text { exercise, reasons fuse, correlate } \\
\text { use with BMI. }\end{array}$ & $\begin{array}{l}30(18 \mathrm{~F}, 12 \mathrm{M}) \text { obese (BMI } 38.3 \\
[9.0]) \text { participants aged } 9 \text { to } 18 \\
(13.0[2.6]) .\end{array}$ & $\begin{array}{l}\text { Few used DDR regularly. Lack } \\
\text { association between DDR use and } \\
\text { change in BMI. }\end{array}$ \\
\hline $\begin{array}{l}\text { Maloney et al., } 2008 \\
{[45,46]}\end{array}$ & $\begin{array}{l}\text { 28-wk comparison of } \\
\text { home-based DDR intervention } \\
\text { focusing on physical activity and } \\
\text { enjoyment. }\end{array}$ & $\begin{array}{l}60 \text { children }(30 \mathrm{M}, 30 \mathrm{~F}) \text { with a } \\
\text { mean age of } 7.5[0.5]\end{array}$ & $\begin{array}{l}\text { DDR use highest in wk } 1 . \text { Mean play } \\
\text { duration } 89 \mathrm{~min} / \mathrm{d} \text {. Use decreased to } \\
\text { half prescribed level by study end. } \\
\text { Sig. reduction in sedentary screen } \\
\text { time in DDR group. }\end{array}$ \\
\hline $\begin{array}{l}\text { McDougall and Duncan, } \\
2008 \text { [47] }\end{array}$ & $\begin{array}{l}\text { Mixed-methods, } \\
\text { noncomparative design of } 1 \mathrm{wk} \\
\text { of lunchtime AVG play. }\end{array}$ & $\begin{array}{l}12 \text { children }(7 \mathrm{~F}, 5 \mathrm{M}) \text { aged } 8-11 \\
\text { years }\end{array}$ & $\begin{array}{l}\text { Mean play duration of } 24 \mathrm{~min} / \mathrm{d} \text {. } \\
\text { Game play resulted in } 10 \% \text { of } \\
\text { recommended steps daily and } \\
11 \text { min sustained } \\
\text { moderate-to-vigorous phys. activity. }\end{array}$ \\
\hline $\begin{array}{l}\text { Mellecker and McManus, } \\
2008 \text { [48] }\end{array}$ & $\begin{array}{l}\text { Comparison study of EE and HR } \\
\text { while seated and during AVG } \\
\text { play. }\end{array}$ & $\begin{array}{l}18 \text { children }(11 \mathrm{M}, 7 \mathrm{~F}) \text { aged } \\
6-12 \text { years }(9.6[1.7])\end{array}$ & $\begin{array}{l}\text { EE above rest sig. higher for } 2 \text { AVGs } \\
\text { compared with seated gaming. HR } \\
\text { sig. higher during bowling and } \\
\text { J-Mat compared to rest. }\end{array}$ \\
\hline
\end{tabular}


Table 1: Continued.

\begin{tabular}{|c|c|c|c|}
\hline Authors & Study description & Sample & Key findings \\
\hline Mellecker et al., 2009 [49] & $\begin{array}{l}\text { Evaluation of newly developed } \\
\text { walking media station for } \\
\text { feasibility of ambulatory screen } \\
\text { time. }\end{array}$ & $\begin{array}{l}29(17 \mathrm{M}, 12 \mathrm{~F}) \text { healthy children } \\
\text { between } 6 \text { and } 13 \text { years old }\end{array}$ & $\begin{array}{l}\text { Steady gait walking achieved in less } \\
\text { than } 1 \text { min. No increase in EE when } \\
\text { computer game added to walking. }\end{array}$ \\
\hline Murphy et al., 2009 [50] & $\begin{array}{l}\text { Determine whether DDR is } \\
\text { effective in improving } \\
\text { endothelial dysfunction in } \\
\text { overweight. Randomly assigned } \\
\text { to } 12 \text { wks of aerobic exercise } \\
\text { using DDR or to a nonexercising } \\
\text { delayed-treatment control group. }\end{array}$ & $\begin{array}{l}35(17 \mathrm{~F}, 18 \mathrm{M}) \text { overweight } \\
\text { children aged } 7-12 \text { years }(10.21) \\
\text { with EDF. }\end{array}$ & $\begin{array}{l}\text { Sig. improvements in FMD, exercise } \\
\text { time, MAP, weight, and peak } \mathrm{VO}_{2} \\
\text { compared with delayed-treatment } \\
\text { group. } 13 \text { intervention participants } \\
\text { achieved normal endothelial } \\
\text { function. }\end{array}$ \\
\hline $\begin{array}{l}\text { Ni Mhurchu et al., } 2008 \\
\text { [51] }\end{array}$ & $\begin{array}{l}\text { Pilot } 12 \text {-wk RCT to evaluate } \\
\text { effect of AVG on phys. activity } \\
\text { levels. Intervention received AVG } \\
\text { upgrade package. Control } \\
\text { received upgrade package at } \\
\text { study end. }\end{array}$ & $\begin{array}{l}20(8 \mathrm{~F}, 12 \mathrm{M}) \text { children aged } \\
10-14 \text { years }(12[1.5]) . \text { Had to } \\
\text { own PlayStation } 2 \text { to be eligible }\end{array}$ & $\begin{array}{l}\text { Phys. activity sig. higher in } \\
\text { intervention group. Reduction in } \\
\text { weight and waist circumference in } \\
\text { intervention group at wk } 12 \text {. }\end{array}$ \\
\hline $\begin{array}{l}\text { Penko and Barkley, } 2010 \\
\text { [52] }\end{array}$ & $\begin{array}{l}\text { Evaluation of physiologic cost, } \\
\text { RRV, and liking. AVG play versus } \\
\text { sedentary video game. }\end{array}$ & $\begin{array}{l}24(12 \mathrm{M}, 12 \mathrm{~F}) \text { children }(11 \\
\text { Lean, } 13 \text { obese) aged } 8 \text { to } 12 \\
\text { years. }\end{array}$ & $\begin{array}{l}\text { Mean } \mathrm{HR}, \mathrm{VO}_{2} \text {, and liking sig. } \\
\text { greater for } \mathrm{AVG} \text { play than all other } \\
\text { conditions. }\end{array}$ \\
\hline Ridley and Olds, 2001 [53] & $\begin{array}{l}\text { Description of EE and child } \\
\text { behavior while visiting game } \\
\text { centres. }\end{array}$ & $\begin{array}{l}134 \text { children from observed. } 10 \\
(5 \mathrm{M}, 5 \mathrm{~F}) \text { children aged } 10-12 \\
\text { years }(12.5[0.5]) \text { evaluated. }\end{array}$ & $\begin{array}{l}\text { Gross energy cost ranged from } 7.6 \\
\text { to } 2.5 \mathrm{ml} \mathrm{kg}^{-1} \mathrm{~min}^{-1} \text {. }\end{array}$ \\
\hline Sit et al., 2010 [54] & $\begin{array}{l}\text { Examining preferences and PA } \\
\text { levels during interactive or } \\
\text { online games. }\end{array}$ & $\begin{array}{l}70(35 \mathrm{~F}, 35 \mathrm{M}) \text { overweight }(20) \\
\text { and nonoverweight }(50) \text { children } \\
\text { aged } 9 \text { to } 12 .\end{array}$ & $\begin{array}{l}\text { Split game time between interactive } \\
(52 \%) \text { and online ( } 48 \%) \text {. Sig. more } \\
\text { moderate-to-vigorous PA with } \\
\text { interactive than online. Boys and } \\
\text { nonoverweight expended more } \\
\text { energy during interactive games } \\
\text { than girls and overweight. }\end{array}$ \\
\hline $\begin{array}{l}\text { Straker and Abbott, } 2007 \\
\text { [55] }\end{array}$ & $\begin{array}{l}\text { Comparison of cardiovascular } \\
\text { response and EE during TV } \\
\text { watching, sedentary gaming, and } \\
\text { AVG play. }\end{array}$ & $\begin{array}{l}20 \text { healthy children }(12 \mathrm{M}, 8 \mathrm{~F}) \\
\text { aged } 9-12 \text { years }\end{array}$ & $\begin{array}{l}\text { AVG play increased EE by } 224 \% \text { and } \\
\text { HR by } 59 \% \text { from rest. AVG play } \\
\text { exertion levels were equivalent to } \\
\text { activities of moderate intensity. }\end{array}$ \\
\hline Unnithan et al., 2006 [56] & $\begin{array}{l}\text { Comparison of energy costs of } \\
\text { playing DDR between } \\
\text { overweight and nonoverweight } \\
\text { kids. }\end{array}$ & $\begin{array}{l}22 \text { children ( } 10 \text { with mild } \\
\text { obesity; } 12 \text { with normal weight) } \\
\text { between } 11 \text { and } 17 \text { years old. }\end{array}$ & $\begin{array}{l}\text { No sig. difference in HR or energy } \\
\text { costs associated with DDR. Average } \\
\mathrm{VO}_{2} \text { with DDR sig. higher in } \\
\text { overweight than nonoverweight. }\end{array}$ \\
\hline \multicolumn{4}{|l|}{ Educational Video Games } \\
\hline $\begin{array}{l}\text { Baranowski et al., } 2011 \\
\text { [57-59] }\end{array}$ & $\begin{array}{l}\text { 2-group RCT evaluation of Diab } \\
\text { and Nanoswarm play in } \\
\text { intervention group versus } \\
\text { control playing website games. }\end{array}$ & $\begin{array}{l}133 \text { children }(45 \% \mathrm{~F}, 58 \% \mathrm{M}) \\
\text { between } 10 \text { and } 12 \text { years old } \\
(42.5 \% 10 \text { years old). BMI } \\
\text { percentile initially } 50 \text { th- } 95 \text { th. }\end{array}$ & $\begin{array}{l}\text { Playing Diab and Nanoswarm } \\
\text { increased daily fruit consumption } \\
\text { by } 0.67 \text { servings but not water } \\
\text { intake, moderate-to-vigorous } \\
\text { physical activity, or body } \\
\text { composition. }\end{array}$ \\
\hline Baranowski et al., 2003 [60] & $\begin{array}{l}2 \text { group RCT ( } 30 \mathrm{~min} / \mathrm{wk}, 8 \text { wks }) \\
\text { to prevent obesity. The Fun, } \\
\text { Food and Fitness! project. }\end{array}$ & $\begin{array}{l}35 \text { African-American girls aged } 8 \\
\text { years }(8.3[0.3] \text { intervention; } 8.4 \\
{[0.3] \text { control) and their }} \\
\text { parents/guardians. }\end{array}$ & $\begin{array}{l}\text { Intervention group consumed } 232 \\
\text { less kcal; greater water, fruit, juice, } \\
\text { and veg. consumption; fewer } \\
\text { sweetened drinks consumed. }\end{array}$ \\
\hline $\begin{array}{l}\text { Baranowski et al., } 2003 \\
{[61,62]}\end{array}$ & $\begin{array}{l}5 \text { wk } 2 \text { group RCT with pre/post } \\
\text { test to increase fruit, juice and } \\
\text { veg intake among healthy } \\
\text { children via Squire's Quest! }\end{array}$ & $\begin{array}{l}26 \text { elementary schools with } 1578 \\
\text { ( } 803 \text { F) 4th-grade students ( } 8729 \\
\text { year olds). }\end{array}$ & $\begin{array}{l}1.0 \text { fruit, juice, and veg. servings } \\
\text { more in intervention group than } \\
\text { control. }\end{array}$ \\
\hline
\end{tabular}


Table 1: Continued.

\begin{tabular}{|c|c|c|c|}
\hline Authors & Study description & Sample & Key findings \\
\hline Moore et al., 2009 [2] & $\begin{array}{l}\text { Effectiveness of Color My } \\
\text { Pyramid and Blast-Off Game on } \\
\text { physical activity and nutrition } \\
\text { knowledge over } 3 \text { month period } \\
\text { (pre/post test). }\end{array}$ & $\begin{array}{l}1264 \text { th-5th (9-11 years old) } \\
\text { grade students }(46 \mathrm{M}, 80 \mathrm{~F}) .\end{array}$ & $\begin{array}{l}\text { Increase in activity time from } \\
\text { pretest to posttest and decrease in } \\
\text { systolic BP for both groups. No sig. } \\
\text { differences in BMI. }\end{array}$ \\
\hline Munguba et al., 2008 [63] & $\begin{array}{l}\text { Evaluation of an occupational } \\
\text { therapy education nutrition } \\
\text { education intvn using } 2 \\
\text { interactive games ( } 1 \text { video game, } \\
1 \text { board game). }\end{array}$ & $\begin{array}{l}200 \text { public school children } \\
\text { between } 8 \text { and } 10 \text { years old ( } 95 \\
\text { M, } 105 \mathrm{~F} \text { ). }\end{array}$ & $\begin{array}{l}\text { Both games promoted learning of } \\
\text { nutritional concepts. }\end{array}$ \\
\hline $\begin{array}{l}\text { Pempek and Calvert, } 2009 \\
{[64]}\end{array}$ & $\begin{array}{l}\text { Examination of how advergames } \\
\text { affect consumption of healthier } \\
\text { and less healthy snacks. }\end{array}$ & $\begin{array}{l}30(15 \mathrm{M}, 15 \mathrm{~F}) \text { low-income } \\
\text { African-American school } \\
\text { children between } 9 \text { and } 10 \text { years } \\
\text { old from } 5 \text { elementary schools }\end{array}$ & $\begin{array}{l}\text { Group playing healthier version of } \\
\text { the game chose and ate more } \\
\text { healthy snacks than less healthy } \\
\text { game group. }\end{array}$ \\
\hline $\begin{array}{l}\text { D. R. Southard and B. H. } \\
\text { Southard, } 2006 \text { [65] }\end{array}$ & $\begin{array}{l}\text { Prelim. results of } 4 \text {-wk RCT } \\
\text { using MetaKenkoh to promote } \\
\text { phys. activity and healthier food } \\
\text { choice. }\end{array}$ & $\begin{array}{l}120 \text { children }(63 \% \mathrm{M}) \text { aged } 9-11 \\
\text { years old. Of which } 13.6 \% \text { are at } \\
\text { risk for overweight, } 25.9 \% \text { are } \\
\text { overweight. }\end{array}$ & $\begin{array}{l}\text { Underweight and normal weight in } \\
\text { intervention group showed increase } \\
\text { in activity. }\end{array}$ \\
\hline Thompson et al., 2009 [66] & $\begin{array}{l}9 \text { wk 2-group RCT evaluating } \\
\text { Boy Scout 5-a-Day Badge on } \\
\text { fruit, juice, and veg. } \\
\text { consumption. With online } \\
\text { knowledge games. }\end{array}$ & $\begin{array}{l}473 \text { boy scouts ( } 42 \text { troops) aged } \\
10-14 \text { years. }\end{array}$ & $\begin{array}{l}\text { Sig. increases in fruit juice } \\
\text { consumption, fruit juice availability } \\
\text { at home, and veg. consumption } \\
\text { self-efficacy in the intervention } \\
\text { group. }\end{array}$ \\
\hline Turnin et al., 2001 [67] & $\begin{array}{l}\text { 2-group RCT evaluation of } \\
\text { knowledge games nutritional } \\
\text { knowledge and improving eating } \\
\text { habits. }\end{array}$ & $\begin{array}{l}18767-12 \text {-year-old } 3 \text { rd-5th } \\
\text { graders }(52.5 \% \text { F) from } 16 \\
\text { schools. }\end{array}$ & $\begin{array}{l}\text { Intervention group sig. better } \\
\text { nutritional knowledge and dietary } \\
\text { intake compared with control. }\end{array}$ \\
\hline
\end{tabular}

AVG: Active Video Game; BMI: Body Mass Index; DDR: Dance Dance Revolution; EE: Energy expenditure; EDF: Endothelial dysfunction; FMD: Flowmediated dilation; HR: Heart Rate; MAP: Mean arterial pressure; Min: Minutes; N: Sample size; P/w: Per week; RCT: Randomized Controlled Trial; RRV: Relative reinforcing value.

Obese children had significantly greater increases in energy expenditure in response to active video games.

Maddison et al. (2007) [43] examined energy expenditure and physical activity associated with playing active and sedentary video games using PlayStation 2 (Sony Corporation, Tokyo, Japan) EyeToy games. Each participant $(N=21)$ completed the study protocol. This involved resting while seated, playing a sedentary video game, and playing active video games (EyeToy Knockout, Homerun, Groove, AntiGrav, and Dance UK). Significant increases in energy expenditure and heart rate were found during active game playing. Step counts increased from 122 to 1288 steps during active video games in comparison to sedentary game play. The energy expended during active video game play was comparable to light or moderate exercise. A recent publication by Maddison et al. (2009) [30] provides an overview of their eGAME study (a 2-arm parallel randomized controlled trial) and includes the plan for Phase 3 which is their future direction. The Phase 3 objective is to determine the effects of an active video game intervention (Sony EyeToy) over 6 months on BMI, body composition, waist circumference, cardiorespiratory fitness, and physical activity levels in 330 overweight children. All Australian participants ranging in age from 10 to 14 years will be randomized to either an active video game upgrade package or to a control group (no intervention). Phase 1 contained focus groups with children, and Phase 2 was a laboratory study (described above).

A 6-month pretest, posttest trial with a noncomparative design was conducted by Madsen et al. (2007) [44]. Obese children $(N=30)$ aged 9-18 years old were provided with DDR and motivated biweekly with a semistructured telephone interview for 24 weeks. The goal was for children to play 30 minutes a day for 5 days a week. Findings show that few children used DDR regularly with a lack of association between DDR use and change in BMI. Children reported that group play, competition, and greater variety would increase their motivation to play.

Maloney et al. (2008) [45, 46] examined physical activity and enjoyment with a controlled group comparison design of an intervention-home-based DDR play-and control group. A total of 60 children between the ages of 7-8 years old participated in a 28-week study. The authors collected self-reported screen time, DDR use, accelerometry, pedometry, body composition, blood pressure and pulse, anthropometry, game satisfaction, and assessment of participation support. Participants played DDR for $89 \mathrm{~min}$ per day (mean) and used the game the most in week 1. Absence of other video games and parent participation was associated with this high level of usage in week 1. By 
the end of the study, usage had decreased to half of the prescribed level. No significant changes in physical activity across both groups were found. The intervention group saw a reduction in sedentary screen time. In week 10, sibling and friend participation was associated with usage of DDR.

McDougall and Duncan (2008) [47] reported a mixedmethods, noncomparative study, where British children $(N=12)$ aged $8-11$ years old engaged in school lunchtime active video game play for 1 week. Children played on average for 24 minutes per day with game play resulting in $10 \%$ to $11 \%$ of the recommended steps allocated daily and 11 minutes of sustained moderate-to-vigorous physical activity per day. Children reported preferring active video games to more traditional forms of activity.

Mellecker and McManus (2008) [48] examined energy expenditure and cardiovascular responses in children during seated (10-pin bowling computer game) and active gaming (XaviX bowling and J-Mat) (Shiseido, Tokyo, Japan). A total of 18 children aged 6 to 12 years participated in a 25 -minute gaming protocol: 5 minutes of seated, 5 minutes of seated bowling, 5 minutes of XaviX bowling, 5 minutes of seated rest, and 5 minutes of XaviX J-Mat. In each game format, energy expenditure was significantly higher than resting (39\% for seated bowling, 98\% for XaviX bowling, 451\% for XaviX J-Mat). Heart rate was significantly higher during gaming than rest. In another study, Mellecker et al. (2009) [49] tested the feasibility of a newly developed walking media station they had created. This station was a treadmill with a screen attached. Twenty-nine healthy children between the ages of 6 and 13 years old tested the media station in a laboratory and home setting. Each participant completed the following protocol: rest, playing a computer bowling game seated, walking, and walking while playing a computer bowling game. No increase in energy cost was found when adding the game to walking. Participants reported that they would use the media station.

Murphy et al. (2009) [50] randomized 35 (17 female, 18 male) overweight children with endothelial dysfunction, between the ages of 7 and 12, to 12 weeks of exercise using DDR or to a nonexercising delayed treatment control group. The exercising intervention group saw significant improvements in flow-mediated dilation, exercise time on a graded test, mean arterial pressure, weight, and peak $\mathrm{VO}_{2}$ compared to the control group. During the study 13 intervention participants achieved normal endothelial function.

A randomized controlled trial conducted by Ni Mhurchu et al. (2008) [51] evaluated the effect of home-based active video game play on the physical activity levels of 20 children aged 10 to 14 years in New Zealand. The intervention group $(N=10)$ received an upgrade package for their Sony PlayStation 2 console, including a Sony EyeToy camera, EyeToy active games, and dance mat. The participants and families were instructed to substitute usual video game play with active video games. The control group received the same upgrade package at the end of the study without an intervention. The authors used the following measurements to evaluate physical activity: accelerometry, self-reported activity, physical activity questionnaire, established activity compendium, anthropometry, and body composition. Results showed that physical activity was significantly higher in the intervention group than the control at both followups. Children in the intervention group spent less total time playing all video games. No significant group differences were found between time spent in moderate or vigorous physical activities. The intervention group showed weight loss $($ mean $=0.13 \mathrm{~kg}$ ) and a reduction in waist circumference $($ mean $=1.4 \mathrm{~cm})$ at the end of 12 weeks.

The physiological cost, relative reinforcing value, and satisfaction of playing Wii Sports bowling compared with Wii PunchOut! (a traditional sedentary video game) was the subject of investigation for Penko and Barkley (2010) [52]. A sample of 11 lean and 13 overweight or obese 8 to 12 year olds participated in 4, 10-minute activity sessions: resting, treadmill walking, sedentary video game play (Wii PunchOut!), and active video game play (Wii Sports Boxing). Participants performed a computer task designed to assess relative reinforcing value. Results showed that average heart rate, oxygen consumption, and liking were significantly greater for Wii than all other conditions.

Ridley and Olds (2001) [53] examined energy cost and observed the behavior of children playing video games and games in an Australian game centre. The authors measured the energy cost of 10 elementary school children ( 5 females and 5 males aged $10-12$, with a mean of 12.5 years) under 5 experimental conditions which were each 5 minutes in duration: seated in front of a sedentary video game and playing 4 games-Daytona (a simulated driving game), Final Furlong (a simulated horse-racing game), Air Hockey (table hockey), and Mini Dunxx (a minibasketball shooting game). Gross energy cost ranged from 7.6 to $2.5 \mathrm{ml} \mathrm{kg}^{-1} \mathrm{~min}^{-1}$.

Sit et al. (2010) [54] conducted a study in Hong Kong examining preferences and physical activity levels during interactive electronic games. Seventy overweight and nonoverweight children aged 9 to 12 participated in 2, 60-minute recreation sessions. Session 1 involved playing either an active (XaviX bowling) or an online bowling game. Session 2 was a choice of an active (Aerostep, Shiseido Co. of Japan) or an online electronic running game. Participants chose to play the games during $94 \%$ of their session time with time split between active (52\%) and online (48\%) gaming. Significant moderate-to-vigorous physical activity was observed during active game play. Participants who were male $(N=35)$ and nonoverweight $(N=50)$ expended relatively more energy during active games than females and overweight children.

A within-subjects design of a comparison between cardiovascular response and energy expended among television watching, sedentary gaming, and active video game play was carried out by Straker and Abbott (2007) [55]. Measures of interest include heart rate, energy expenditure, oxygen uptake, and ventilation. Twenty healthy $9-12$-year-old children, who had previous experience with playing electronic games, were recruited. Heart rate and energy expenditure were comparable for television watching and sedentary gaming. Energy expenditure and heart rate increased from resting during active video gaming (Sony EyeToy) by $224 \%$ 
and 59\%, respectively. The exertion levels observed during active video game play were equivalent to moderate intensity activity.

Unnithan et al. (2006) [56] determined the difference between the submaximal energy cost of movement and cardiorespiratory measures for overweight and nonoverweight children playing DDR. Each group of children $(N=22)$ completed 12 minutes of DDR and a maximal treadmill walking test. There was no difference in heart rate and energy costs associated with DDR between overweight and nonoverweight groups. Heart rate intensity levels, but not oxygen consumption reserve, were sufficient for developing and maintaining cardiorespiratory fitness.

3.2. Video Games. These games are either stand-alone or embedded within a larger intervention study containing elements such as face-to-face group education sessions. The games referred to in this section are developed by the respective researchers.

Two interactive video games developed by Baranowski et al. (2011) [57-59] targeting healthier food choices (fruit and vegetable consumption), body composition, and physical activity were evaluated in a 2-group randomized controlled trial. Participants $(N=133)$ aged 10 to 12 years participated in either the intervention group, which played "Escape from Diab" and "Nanoswarm: Attack from Inner Space" in sequence, or the control group, which played diet and physical activity knowledge-based games on popular websites. The authors found that playing the video games in the intervention increased fruit consumption by 0.67 servings per day but did not increase water intake, moderateto-vigorous physical activity, or body composition.

The Fun, Food, and Fitness Project [60] is a randomized 2-arm parallel randomized controlled trial designed to prevent obesity. This 12 -week intervention, taking place at a summer day camp and at home, was designed to motivate the participants $(N=35,8$ years old, African-American females) to eat 5 servings of fruit and vegetables, drink 5 glasses of water, and engage in 30 minutes of physical activity per day. Participants in the intervention group attended a special 4-week summer day camp and received an 8-week home internet intervention featuring a computer game with comic strip characters who overcome barriers to goals with regard to physical activity. The control group attended a summer camp with usual activities followed by a monthly home internet intervention without the game. Results showed significant difference in BMI between both groups.

"Squire's Quest" [61, 62] is a multimedia game that aims to increase preferences for fruit, juice, and vegetable consumption among children. In a 2-group randomized controlled trial, Baranowski et al. (2003) evaluated the effectiveness of this game. A population of 1578 4th grade students were recruited to participate in the study. The intervention group received 10 sessions twice a week with a duration of 25 minutes of "Squire's Quest." The control group did not receive the intervention. Findings indicate an increase of fruit and vegetables servings per day (1.0) in the intervention group.
The "MyPyramid Blast-Off Game" educates children about the food pyramid and physical activity [2]. In a pretest, posttest study Moore et al. (2009) examined the effect of a nutrition education program "Color My Pyramid" (United States Department of Agriculture, 2007). A total of 126, 4th and 5th grade Washington, DC students took part in an intervention of 6 classes taught over 3 months aimed at increasing knowledge about nutrition and physical activity. Both schools received the educations and activity content. While 1 school received a more didactic presentation on playing the "Blast-Off Game," the other school required students to use individual computers to evaluate their diets in small groups. This program included the interactive computer game described above. Results of this study show an increase in nutrition knowledge of the control group. In both groups activity time was increased and systolic blood pressure decreased. No significant differences in BMI were seen.

Munguba et al. (2008) [63] evaluated the use of 2 interactive games - a video game and a board game that were interconnected in relation to theme, character, and foodsin a nutrition education program for obese children in Brazil. Two hundred children aged 8-10 years took part in this study with each taking part in weekly 30-minute game sessions over a 4-month period. Both games were based on the food pyramid and promoted the learning of nutritional concepts. Participants preferred the video game (27\% compared to $6 \%)$.

Pempek and Calvert (2009) [64] reported a crosssectional study examining how marketing games (advergames) affect the consumption of snack type. Participants (30 low-income 3rd- and 4th-grade AfricanAmerican children) were randomly assigned to 1 of 3 conditions of which they would play 2 levels of each game: a healthier advergame, a less healthy advergame, or the control group. The classic arcade game Pac-Man (Namco, Tokyo, Japan) was used as a prototype for 2 versions created. In the healthier game option, 10 points were awarded for each nutritious snack eaten and penalized the same amount of points for every less nutritious snack. While in the less healthy option children were rewarded 10 points for every less nutritious snack and penalized for every healthier snack eaten. In the intervention groups children were asked to choose a snack after they played the game. In the control group snack selection took place before the game. The children playing the healthier version of the game selected and ate significantly more healthy snacks.

"MetaKenkoh" is an internet-based adventure game that targets physical activity promotion and healthier food choices [65]. D. R. Southard and B. H. Southard (2006) present preliminary results of a 4-week randomized controlled trial of 63 children aged 9-11 years. Intervention group participants played a game and wore a pedometer (with the pedometer controlling game performance). In contrast the control group was monitored without video game playing. Within 1 week, underweight and normal weight children in the intervention group showed an increase in activity. In comparison, a decrease in physical activity 
was observed in the control group. The overweight and atrisk participants in both groups showed a slight increase in activity levels.

In the Boy Scout 5 -a-Day Badge study, 473 boy scouts aged 10 to 14 years old participated in a 2-group randomized controlled trial for 9 weeks [66]. This program was aimed at increasing fruit and vegetable consumption that included knowledge games focusing on diet and contained interactive comic characters that underwent challenges to eating more fruits and vegetables. While the game cannot be evaluated by its own, the study saw an increase of 0.83 servings per day of fruit and vegetable and a 1.24 increase in fruit and vegetable items available at home in the intervention group.

Turnin et al. (2001) [67] conducted a 2-group randomized controlled trial in 1876 , 3rd to 5th graders (16 schools) evaluating 4 nutritional teaching computer games aimed at increasing nutritional knowledge and improving eating habits. The schools taking part (16) were randomized into 2 groups: an intervention group, which received nutritional learning games; and a control group, where a teacher provided the nutritional information. Participants played "Store" (categorization of food), "Guess who" (food contents), "Granny Smith" (food choices), and "The Restaurant" (nutritional balance) for 1 hour twice a week for 5 weeks. A significant improvement in nutritional knowledge and dietary intake was noted amongst intervention participants.

\section{Discussion and Conclusions}

Researchers have utilized a number of commercial active video games or new-generation video games in an effort to quantify their impact on children's physical activity levels. The games included in the reviewed papers are Aerostep; Dance Dance Revolution; Wii Sports; Freekstyle; Nicktoons Movin'; EyeToy games such as Knockout, XaviX bowling; XaviX J-Mat.

Educational video games, either as a stand-alone or part of a larger intervention, are predominantly focused on dietary and nutrition issues. Games included in this paper include Escape from Diab, Guess who, Granny Smith, Nanoswarm, Squire's Quest, MyPyramid Blast-off Game, The Restaurant, an altered version of Pac-Man, MetaKenkoh, and Store.

Assumptions are often made about the value of video games and their potential to improve lifestyle and dietary habits. Although video games may have benefit, it is equally important to have an evidence-based approach to developing and evaluating these games-as they are in fact an intervention. Appropriate strategies to evaluate the games and deliver them in ways that are reproducible are important from a knowledge translation perspective. We found a lot of heterogeneity in terms of the outcomes also, both the metrics that were used and the methods of measurement. It may be time to consider some guidance for those who design and use these games in research to have common metrics that can be compared across different games. This will, in the future, allow us to provide more relevant and interpretable comparisons.
Evidence is indisputable about the need for an ecological, multilevel approach in childhood obesity interventions. Educating both the parent and child, given the complex interactions between social determinants in a family setting, is essential to the success of an intervention. It is unreasonable to expect a total and significant behaviour change or outcome based on modifying nutrition knowledge alone. While education is undoubtedly important for motivating behaviour change, other factors such as home environment, parent income, and parental education level have been implicated in obesity. Although a parent's knowledge of healthful eating and their socioeconomic status may play a role in obesity, it is necessary to note these 2 factors may not be the main driving forces. A recent report of National Health and Nutrition Examination Survey data showed that (a) childhood obesity prevalence decreased as the education level of the head of the household increased; however, this trend was not consistent across race and ethnicity and (b) the majority of children and adolescents who are obese are not from low-income households [3]. This suggests that a lack of financial resources may not be a main barrier to healthful eating. Further research is needed looking at the role an "educated" child can play in transforming the outlook of the family as parents. While additional research is needed to understand and determine the most effective avenues to promote healthy eating, it is well supported that educating children in healthy eating not only provides immediate benefit but fosters long-term health habits as well. Thus, while active and serious gaming poses an excellent opportunity for increased physical activity and nutritional knowledge, it is not a sole solution to the obesity epidemic among children. Looking at integrating AVG and educational gaming in classroom settings or in collaboration with community or national level programs such as the Expanded Food and Nutrition Education Program (EFNEP) [68] is a potential step forward to using gaming as a tool for combating obesity.

Research has proven that AVG use can elicit light to moderate physical activity among youth. While we are not advocating that a child only plays video games to get their recommended daily physical activity, we are proposing that physical activity as a result of AVG engagement can contribute toward daily recommendations of physical activity.

Gaming companies invest significant resources into determining the multifactors that influence choice and duration of game use. So the question becomes, how can we sustain use of health promoting games in children? One avenue of exploration is the involvement of the family unit-parents and siblings. Emphasizing the social aspects of gaming, including competition and feelings of camaraderie, may be an effective means of promoting game use. A review conducted by Biddiss and Irwin (2010) [28] found "fun" to be the primary reason for participation in physical activity. Conducting needs assessments to determine what game factors constitute "fun" may not only encourage physical activity while gaming but additionally promote user sustainability.

Given the fact that a child's attention is already captured by video gaming, why not develop games targeted at obesity 
reduction that use active "new generation" style games to increase children's knowledge and self-care ability? The time that children already spend playing video games can be simultaneously used to promote physical activity and health behavior education. The climate in North America lends itself to periodic episodes of limited outdoor play thus making safe, indoor play an easier option. Capitalizing on the novelty of active video gaming can encourage physical activity and simultaneous learning, a strategy which again may promote sustained use of the game.

Engaging participants in game development is a strategy employed by many corporations. By examining product development and marketing strategies, health games could further ensure audience acceptability and investment. Using these strategies in a pure research setting may prove advantages when developing an appropriate and effective AVG for overweight and obese children.

Self-initiation and choice are key factors in motivating physical activity among children [28]. Intrinsic motivators such as enjoyment, mastery, and achievement drive initiation and long-term continuation with behaviors [35]. Biddiss and Erwin (2010) suggest five strategies on how to sustain video game play in children. First, AVGs must provide positive feedback and be accessible through low cost and ease of use. Second, early exposure to active gaming, as opposed to passive or sedentary gaming, may encourage greater acceptance of AVGs; this strategy may allude to a future need for games that appeal to a wide range of ages and interests. Third, acceptance and motivation to play AVGs may increase when game play is perceived as a personal choice rather than a prescribed treatment therapy. And finally, short- and longterm reinforcement (i.e., enjoyment, goal-achievement, and skills development, resp.) are needed to ensure long-term adherence to game play.

Additional research on video gaming and motivation is required to explore goal setting and achievement as well as factors that initiate game play among children. Also, intensities and durations of physical activity over extended periods ( $>12$ months) must be analyzed [35]. A propensity toward short-term home-based studies has curtailed research in long-term adherence and efficacy of AVG use among children ( $>7$ months) [45]. Additional long-term research is required to determine the role of game diversification, the importance of story or plot development in AVGs, and the potential benefits of group play. While these strategies have been successful for short-term game play, their role in longterm adherence and efficacy is yet to be determined [44].

Given the prevalence of past studies and media attention towards the negative effects of video gaming (e.g., increased screen time), it is important to consider the potential barriers that may impede AVG use. Research into overcoming potential barriers would be advantageous to the future of health gaming.

An interesting avenue for future research is the potential of AVG play as an entry way into organized sports. Psychological factors accompanying AVG play may include increases to self-efficacy, self-competency, and self-empowerment. These qualities may be translated to an increase in confidence and attitudes towards organized sports, ultimately leading to a greater likelihood of the child participating in organized sports activities. As children learn and become more familiar with the rules and play of sports activities, they may become more inclined to participate in physical activity.

An additional area to question and possibly incorporate into the research is what value do people put on their health? The premise is that people will want to play games that improved their self-health and quality of life. However, we do not really know whether people play games, because it is a game. Knowing this will help us design games that clearly state that their value has more subtle or "hidden" benefits so the patient is blinded to the intent. If people value their health, they may be more likely to engage in healthful behaviours in a sustainable way rather than sporadically. Would knowing that the game is aimed at promoting healthy behaviour encourage or impede the use of the intervention by children?

Clearly with the environmental constraints in both emerging economies and developed economies, where access to green space and exercise facilities is limited, consideration has to be given to other avenues for exercise, which makes a good case for healthful games.

Interdisciplinary research teams would prove invaluable to the development of health video games; individuals with specialized knowledge in one field may collaborate with an expert in another to ensure a tailored intervention.

The stigmatization of video gaming, with implications of increased sedentary screen time and decrease in physical activity, is slowly being eroded by the advancement of active video games. The potential of active video gaming or exergaming in the fight against childhood obesity is evidenced through the studies referenced in this paper. However it is also important to consider interactive educational video games that aid in self-management and skill building as an equally valuable tool to combat childhood obesity. In a society so dependent on technology, using that dependency to create a more healthful existence becomes an easy choice.

The popularity of games such as Farmville (Zynga Inc.) and the realms of Second Life (Linden Research Inc.) suggest a new avenue of games in obesity prevention and self-care: social gaming. Rather than fight the enormous role (given how many hours children spend playing them) gaming has in children and adolescent's lives, we should embrace the opportunity to influence health behaviour through this avenue and use an evidence-based approach to do this in a thoughtful way. Otherwise we risk sporadic outcomes, where commercial interests dominate use.

\section{References}

[1] A. P. Rocchini, "Childhood obesity and a diabetes epidemic," The New England Journal of Medicine, vol. 346, no. 11, pp. 854855, 2002.

[2] J. B. Moore, L. R. Pawloski, P. Goldberg, K. M. Oh, A. Stoehr, and H. Baghi, "Childhood obesity study: a pilot study of the effect of the nutrition education program Color My Pyramid," Journal of School Nursing, vol. 25, no. 3, pp. 230-239, 2009.

[3] C. L. Ogden, M. M. Lamb, M. D. Carroll, and K. M. Flegal, "Obesity and socioeconomic status in children and adolescents: United States, 2005-2008,” 2010. 
[4] Y. M. Kim and S. J. Lee, "Physical activity and abdominal obesity in youth," Applied Physiology, Nutrition and Metabolism, vol. 34, no. 4, pp. 571-581, 2009.

[5] J. J. Reilly, E. Methven, Z. C. McDowell et al., "Health consequences of obesity," Archives of Disease in Childhood, vol. 88, no. 9, pp. 748-752, 2003.

[6] L. R. Hardy, J. S. Harrell, and R. A. Bell, "Overweight in children: definitions, measurements, confounding factors, and health consequences," Journal of Pediatric Nursing, vol. 19, no. 6, pp. 376-384, 2004.

[7] L. DeMattia and S. L. Denney, "Childhood obesity prevention: successful community-based efforts," Annals of the American Academy of Political and Social Science, vol. 615, no. 1, pp. 8399, 2008.

[8] A. J. Atkin, T. Gorely, S. J. H. Biddle, S. J. Marshall, and N. Cameron, "Critical hours: physical activity and sedentary behavior of adolescents after school," Pediatric Exercise Science, vol. 20, no. 4, pp. 446-456, 2008.

[9] C. Boreham and C. Riddoch, "The physical activity, fitness and health of children," Journal of Sports Sciences, vol. 19, no. 12, pp. 915-929, 2001.

[10] W. B. Strong, R. M. Malina, C. J. R. Blimkie et al., "Evidence based physical activity for school-age youth," The Journal of Pediatrics, vol. 146, no. 6, pp. 732-737, 2005.

[11] B. Gutin, P. Barbeau, S. Owens et al., "Effects of exercise intensity on cardiovascular fitness, total body composition, and visceral adiposity of obese adolescents," The American Journal of Clinical Nutrition, vol. 75, no. 5, pp. 818-826, 2002.

[12] S. Y. S. Kimm, N. W. Glynn, E. Obarzanek et al., "Relation between the changes in physical activity and body-mass index during adolescence: a multicentre longitudinal study," The Lancet, vol. 366, no. 9482, pp. 301-307, 2005.

[13] L. M. LeMura and M. T. Maziekas, "Factors that alter body fat, body mass, and fat-free mass in pediatric obesity," Medicine and Science in Sports and Exercise, vol. 34, no. 3, pp. 487-496, 2002.

[14] R. Telama, X. Yang, J. Viikari, I. Välimäki, O. Wanne, and O. Raitakari, "Physical activity from childhood to adulthood: a 21-year tracking study," American Journal of Preventive Medicine, vol. 28, no. 3, pp. 267-273, 2005.

[15] J. W. R. Twisk, H. C. G. Kemper, and W. Van Mechelen, "Tracking of activity and fitness and the relationship with cardiovascular disease risk factors," Medicine and Science in Sports and Exercise, vol. 32, no. 8, pp. 1455-1461, 2000.

[16] T. Lobstein, L. Baur, and R. Uauy, "Obesity in children and young people: a crisis in public health," Obesity Reviews, Supplement, vol. 5, supplement 1, pp. 4-104, 2004.

[17] K. S. Steinbeck, "The importance of physical activity in the prevention of overweight and obesity in childhood: a review and an opinion," Obesity Reviews, vol. 2, no. 2, pp. 117-130, 2001.

[18] Active Healthy Kids Canada, "Healthy Habits Start Earlier Than You Think. The Active Healthy Kids Canada Report Card on Physical Activity for Children and Youth," 2010, http://www.activehealthykids.ca/ecms.ashx/ 2010ActiveHealthyKidsCanadaReportCard-shortform.pdf.

[19] J. D. Wright, C. Y. Wang, J. Kennedy-Stephenson, and R. B. Ervin, "Dietary intake of ten key nutrients for public health, United States: 1999-2000," Advance Data, no. 334, pp. 1-4, 2003.

[20] K. Patrick, K. J. Calfas, G. J. Norman et al., "Randomized controlled trial of a primary care and home-based intervention for physical activity and nutrition behaviors: PACE+ for adolescents," Archives of Pediatrics \& Adolescent Medicine, vol. 160, no. 2, pp. 128-136, 2006.

[21] R. Wahl, "Nutrition in the adolescent," Pediatric Annals, vol. 28, no. 2, pp. 107-111, 1999.

[22] N. F. Krebs, J. H. Himes, D. Jacobson, T. A. Nicklas, P. Guilday, and D. Styne, "Assessment of child and adolescent overweight and obesity," Pediatrics, vol. 120, supplement 4, pp. S193-228, 2007.

[23] United States Department of Agriculture, "Dietary Guidelines for Americans 2011,” 2011, http://www.cnpp.usda.gov/ dietaryguidelines.htm.

[24] U.S. Department of Health \& Human Services, "The Surgeon General's Vision for a Healthy and Fit Nation Fact Sheet 2010," 2011, http://www.surgeongeneral.gov/library/obesityvision/ obesityvision2010.pdf.

[25] Centers for Disease Control and Prevention, "How much physical activity do children need? 2010," 2011, http://www .cdc.gov/physicalactivity/everyone/guidelines/children.html.

[26] E. M.F. Van Sluijs, A. M. McMinn, and S. J. Griffin, "Effectiveness of interventions to promote physical activity in children and adolescents: systematic review of controlled trials," British Medical Journal, vol. 335, no. 7622, pp. 703-707, 2007.

[27] M. Frenn, S. Malin, R. L. Brown et al., "Changing the tide: an internet/video exercise and low-fat diet intervention with middle-school students," Applied Nursing Research, vol. 18, no. 1, pp. 13-21, 2005.

[28] E. Biddiss and J. Irwin, "Active video games to promote physical activity in children and youth: a systematic review," Archives of Pediatrics \& Adolescent Medicine, vol. 164, no. 7, pp. 664-672, 2010.

[29] E. A. Vandewater, M. S. Shim, and A. G. Caplovitz, "Linking obesity and activity level with children's television and video game use," Journal of Adolescence, vol. 27, no. 1, pp. 71-85, 2004.

[30] R. Maddison, L. Foley, C. Ni Mhurchu et al., "Feasibility, design and conduct of a pragmatic randomized controlled trial to reduce overweight and obesity in children: the electronic games to aid motivation to exercise (eGAME) study," BMC Public Health, vol. 9, article 146, 2009.

[31] Z. Wilson, "Pew survey: teens love facebook, hate blogging, are always online, and don't use twitter," 2010, http://www .fastcompany.com/blog/zachary-wilson/and-how/pew-survey -finds-increase-social-media-internet-time-decrese-blogging -te.

[32] Center for the Digital Future, "Annual internet survey by the center for the digital future finds large increases in use of online newspapers 2009: 1-9," USC Annenberg School for Communication, http://www.digitalcenter.org/pdf/ 2009_Digital_Future_Project_Release_Highlights.pdf.

[33] A. J. Daley, "Can exergaming contribute to improving physical activity levels and health outcomes in children?" Pediatrics, vol. 124, no. 2, pp. 763-771, 2009.

[34] JO. Salmon, M. L. Booth, P. Phongsavan, N. Murphy, and A. Timperio, "Promoting physical activity participation among children and adolescents," Epidemiologic Reviews, vol. 29, no. 1, pp. 144-159, 2007.

[35] T. Baranowski, R. Buday, D. I. Thompson, and J. Baranowski, "Playing for real: video games and stories for health-related behavior change," American Journal of Preventive Medicine, vol. 34, no. 1, pp. 74-82, 2008.

[36] M. J.M. Chin A Paw, W. M. Jacobs, E. P.G. Vaessen, S. Titze, and W. van Mechelen, "The motivation of children to play an active video game," Journal of Science and Medicine in Sport, vol. 11, no. 2, pp. 163-166, 2008. 
[37] L. H. Epstein, M. D. Beecher, J. L. Graf, and J. N. Roemmich, "Choice of interactive dance and bicycle games in overweight and nonoverweight youth," Annals of Behavioral Medicine, vol. 33, no. 2, pp. 124-131, 2007.

[38] D. L. Graf, L. V. Pratt, C. N. Hester, and K. R. Short, "Playing active video games increases energy expenditure in children," Pediatrics, vol. 124, no. 2, pp. 534-540, 2009.

[39] L. Graves, G. Stratton, N. D. Ridgers, and N. T. Cable, "Energy expenditure in adolescents playing new generation computer games," British Medical Journal, vol. 335, no. 7633, pp. 12821284, 2007.

[40] L. E. F. Graves, N. D. Ridgers, and G. Stratton, "The contribution of upper limb and total body movement to adolescents' energy expenditure whilst playing Nintendo Wii," European Journal of Applied Physiology, vol. 104, no. 4, pp. 617-623, 2008.

[41] B. L. Haddock, S. R. Siegel, and L. D. Wikin, "The addition of a video game to stationary cycling: the impact on energy expenditure in overweight children," The Open Sports Sciences Journal, vol. 2, pp. 42-46, 2009.

[42] L. Lanningham-Foster, T. B. Jensen, R. C. Foster et al., "Energy expenditure of sedentary screen time compared with active screen time for children," Pediatrics, vol. 118, no. 6, pp. e1831e1835, 2006.

[43] R. Maddison, C. Ni Mhurchu, A. Jull, Y. Jiang, H. Prapavessis, and A. Rodgers, "Energy expended playing video console games: an opportunity to increase children's physical activity?" Pediatric Exercise Science, vol. 19, no. 3, pp. 334-343, 2007.

[44] K. A. Madsen, S. Yen, L. Wlasiuk, T. B. Newman, and R. Lustig, "Feasibility of a dance videogame to promote weight loss among overweight children and adolescents," Archives of Pediatrics \& Adolescent Medicine, vol. 161, no. 1, pp. 105-107, 2007.

[45] A. E. Maloney, T. C. Bethea, K. S. Kelsey et al., "A pilot of a video game (DDR) to promote physical activity and decrease sedentary screen time," Obesity, vol. 16, no. 9, pp. 2074-2080, 2008.

[46] S. Paez, A. Maloney, K. Kelsey, C. Wiesen, and A. Rosenberg, "Parental and environmental factors associated with physical activity among children participating in an active video game," Pediatric Physical Therapy, vol. 21, no. 3, pp. 245-253, 2009.

[47] J. McDougall and M. J. Duncan, "Children, video games and physical activity: an exploratory study," International Journal on Disability and Human Development, vol. 7, no. 1, pp. 8994, 2008.

[48] R. R. Mellecker and A. M. McManus, "Energy expenditure and cardiovascular responses to seated and active gaming in children," Archives of Pediatrics \& Adolescent Medicine, vol. 162, no. 9, pp. 886-891, 2008.

[49] R. R. Mellecker, A. M. McManus, L. M. Lanningham-Foster, and J. A. Levine, "The feasibility of ambulatory screen time in children," International Journal of Pediatric Obesity, vol. 4, no. 2, pp. 106-111, 2009.

[50] E. C. S. Murphy, L. Carson, W. Neal, C. Baylis, D. Donley, and R. Yeater, "Effects of an exercise intervention using Dance Dance Revolution on endothelial function and other risk factors in overweight children," International Journal of Pediatric Obesity, vol. 4, no. 4, pp. 205-214, 2009.

[51] C. Ni Mhurchu, R. Maddison, Y. Jiang, A. Jull, H. Prapavessis, and A. Rodgers, "Couch potatoes to jumping beans: a pilot study of the effect of active video games on physical activity in children," International Journal of Behavioral Nutrition and Physical Activity, vol. 5, article 8, 2008.
[52] A. L. Penko and J. E. Barkley, "Motivation and physiologic responses of playing a physically interactive video game relative to a sedentary alternative in children," Annals of Behavioral Medicine, pp. 1-8, 2010.

[53] K. Ridley and T. Olds, "Video center games: energy cost and children's behaviors," Pediatric Exercise Science, vol. 13, no. 4, pp. 413-421, 2001.

[54] C. H. Sit, J. W. Lam, and T. L. McKenzie, "Direct observation of children's preferences and activity levels during interactive and online electronic games," Journal of Physical Activity \& Health, vol. 7, no. 4, pp. 484-489, 2010.

[55] L. Straker and R. Abbott, "Effect of screen-based media on energy expenditure and heart rate in 9- to 12-year-old children," Pediatric Exercise Science, vol. 19, no. 4, pp. 459-471, 2007.

[56] V. B. Unnithan, W. Houser, and B. Fernhall, "Evaluation of the energy cost of playing a dance simulation video game in overweight and non-overweight children and adolescents," International Journal of Sports Medicine, vol. 27, no. 10, pp. 804-809, 2006.

[57] T. Baranowski, J. Baranowski, D. Thompson et al., "Video game play, child diet, and physical activity behavior change: a randomized clinical trial," American Journal of Preventive Medicine, vol. 40, no. 1, pp. 33-38, 2011.

[58] D. Thompson, T. Baranowski, R. Buday et al., "Serious video games for health: how behavioral science guided the development of a serious video game," Simulation and Gaming, vol. 41, no. 4, pp. 587-606, 2010.

[59] D. Thompson, T. Baranowski, R. Buday et al., "In pursuit of change: youth response to intensive goal setting embedded in a serious video game," Journal of Diabetes Science and Technology, vol. 1, pp. 907-917, 2007.

[60] T. Baranowski, J. C. Baranowski, K. W. Cullen et al., "The fun, food, and fitness project (FFFP): the baylor GEMS pilot study," Ethnicity \& Disease, vol. 13, no. 1, pp. S1-S1, 2003.

[61] T. Baranowski, J. Baranowski, K. W. Cullen et al., "Squire's Quest!: dietary outcome evaluation of a multimedia game," American Journal of Preventive Medicine, vol. 24, no. 1, pp. 5261, 2003.

[62] K. W. Cullen, K. Watson, T. Baranowski, J. H. Baranowski, and I. Zakeri, "Squire's quest: intervention changes occurred at lunch and snack meals," Appetite, vol. 45, no. 2, pp. 148151, 2005.

[63] M. C. Munguba, M. T. M. Valdés, and C. A. B. da Silva, "The application of an occupational therapy nutrition education programme for children who are obese," Occupational Therapy International, vol. 15, no. 1, pp. 56-70, 2008.

[64] T. A. Pempek and S. L. Calvert, "Tipping the balance: use of advergames to promote consumption of nutritious foods and beverages by low-income African American children," Archives of Pediatrics \& Adolescent Medicine, vol. 163, no. 7, pp. 633637, 2009.

[65] D. R. Southard and B. H. Southard, "Promoting physical activity in children with MetaKenkoh," Clinical and Investigative Medicine, vol. 29, no. 5, pp. 293-297, 2006.

[66] D. Thompson, T. Baranowski, J. Baranowski et al., "Boy Scout 5-a-Day Badge: outcome results of a troop and Internet intervention," Preventive Medicine, vol. 49, no. 6, pp. 518-526, 2009.

[67] M. C. Turnin, M. T. Tauber, O. Couvaras et al., "Evaluation of microcomputer nutritional teaching games in 1,876 children at school," Diabetes and Metabolism, vol. 27, no. 4, pp. 459464, 2001. 
[68] United States Department of Agriculture, "Expanded Food and Nutrition Education Program (EFNEP) 2010,” 2011, http://www.csrees.usda.gov/nea/food/efnep/efnep.html . 


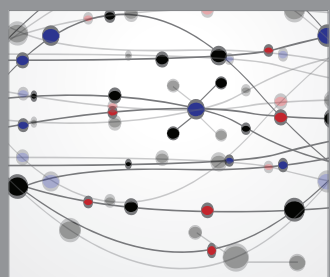

The Scientific World Journal
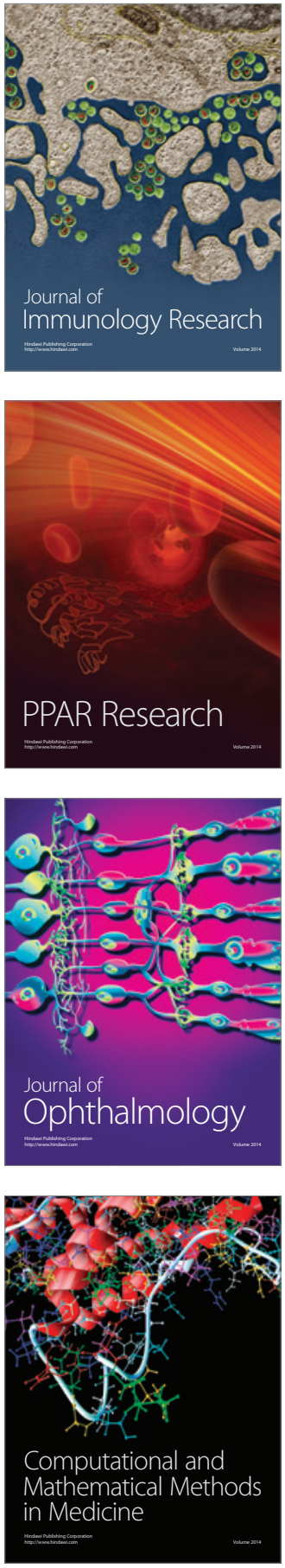

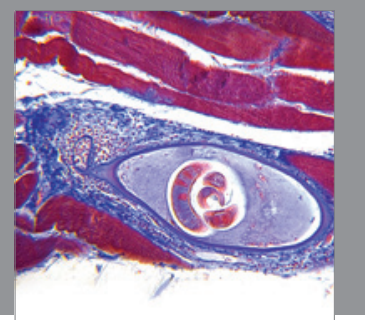

Gastroenterology

Research and Practice
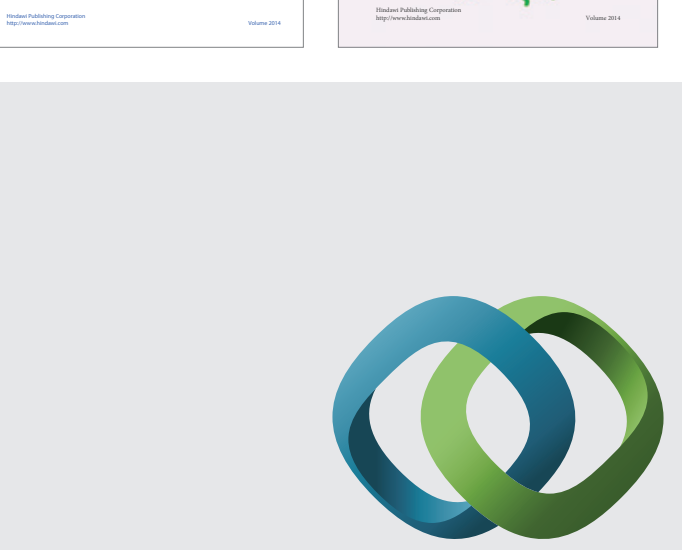

\section{Hindawi}

Submit your manuscripts at

http://www.hindawi.com
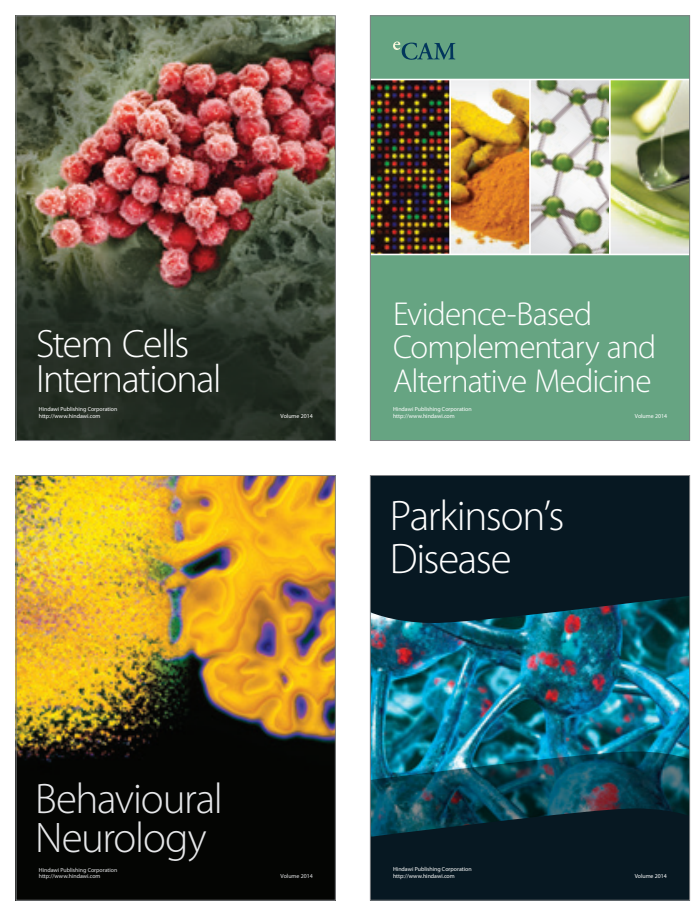

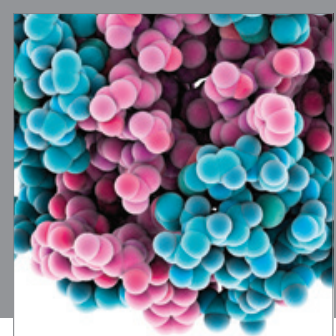

Journal of
Diabetes Research

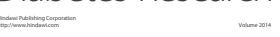

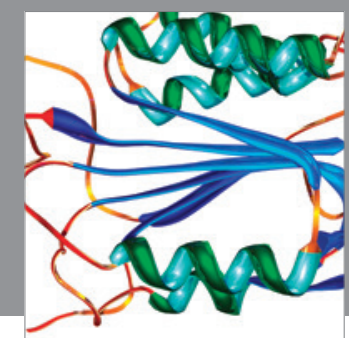

Disease Markers
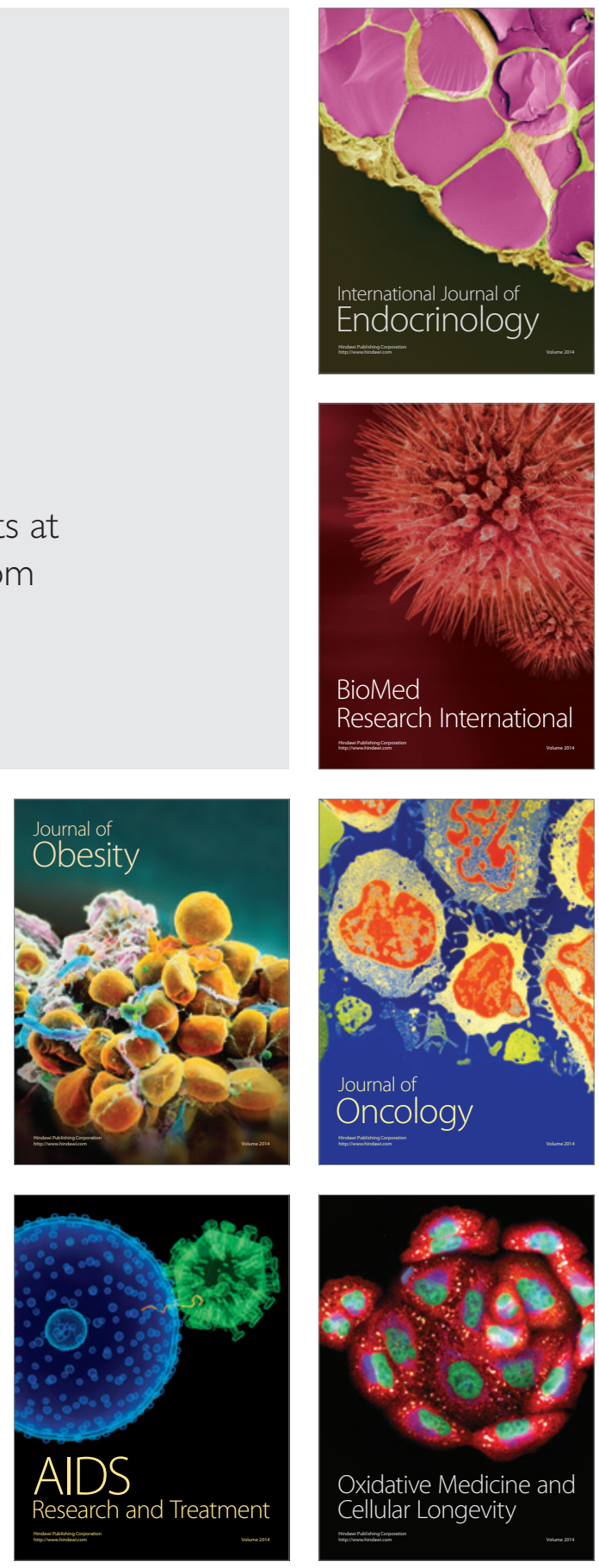